\title{
Plasma levels of progastrin but not amidated gastrin or glycine extended gastrin are elevated in patients with colorectal carcinoma
}

\author{
R K Siddheshwar, J C Gray, S B Kelly
}

\begin{abstract}
Background-The relationship between plasma gastrin levels and colorectal cancer is controversial. When confounding factors which increase plasma gastrin levels are taken into account, it has been shown that gastrin levels are not elevated in patients with colorectal cancer. However, these studies only measured amidated gastrin. Total gastrin (which includes unprocessed, partially processed, and mature forms of gastrin) has been shown to be elevated in patients with colorectal cancer.

Aims-The aim of this study was to determine whether fasting plasma levels of progastrin, amidated gastrin, or glycine extended gastrin are elevated in patients with colorectal cancer or colorectal polyps compared with controls.
\end{abstract}

Methods-Progastrin, amidated gastrin, and glycine extended gastrin were estimated by radioimmunoassay using the following antibodies: L289, 109-21, and L2. Blood samples were analysed for Helicobacter pylori by an enzyme linked immunosorbent assay.

Results-Median progastrin levels were significantly higher in the cancer group $(27.5 \mathrm{pmol} / \mathrm{l})$ than in the polyp $(\leqslant 15$ pmol/1) or control ( $\leqslant 15 \mathrm{pmol} / \mathrm{l})$ group $(p=0.0001)$. There was no difference in median levels of amidated gastrin between groups. Median levels of amidated gastrin were significantly higher in $H$ pylori positive patients $(19 \mathrm{pmol} / \mathrm{l})$ than in $H$ pylori negative patients $(8 \mathrm{pmol} / \mathrm{l})(\mathrm{p}=0.0022)$. Median plasma progastrin levels were significantly higher for moderately dysplastic polyps (38 pmol/1) compared with mildly dysplastic (15 pmol/1) and severely dysplastic $(15 \mathrm{pmol} / \mathrm{l})$ polyps $(\mathrm{p}=0.05)$.

Conclusions-Plasma levels of progastrin, but not amidated gastrin or glycine extended gastrin, are significantly elevated in patients with colorectal cancer compared with those with colorectal polyps or controls, irrespective of their $H$ pylori status. We conclude that measuring plasma progastrin levels in patients with colorectal cancer is warranted.

(Gut 2001;48:47-52)

Keywords: progastrin; glycine extended gastrin; colorectal carcinoma

Colorectal cancer is the second most common malignant disease in the UK after lung cancer, and accounts for about 26000 new cases and
20000 deaths each year. The relationship between gastrin and the development of colorectal cancer remains controversial. Gastrin stimulates colonic proliferation ${ }^{12}$ and growth of colonic cell lines in vitro ${ }^{34}$ and colorectal carcinoma in vivo. ${ }^{56}$ It has been shown that glycine extended gastrin exerts a mitogenic effect on a human colon cancer cell line $\mathrm{e}^{7}$ and a non-transformed colon cell line. ${ }^{8}$ Nemeth and colleagues $^{9}$ demonstrated production of progastrin by colorectal tumours. Seva and colleagues ${ }^{10}$ observed a proliferative effect of both amidated gastrin and glycine extended gastrin on the exocrine pancreatic cell line AR4-2J. Transgenic mice producing progastrin in the liver have increased plasma progastrin levels and hyperplasia of the colonic mucosa. ${ }^{11}$ Koh and colleagues ${ }^{12}$ demonstrated decreased epithelial proliferation of the colonic mucosa in gastrin deficient mice. Gastrin receptors have been demonstrated on colorectal carcinomas. ${ }^{13}$ Gastrin receptor antagonists and antigastrin antibodies inhibit the growth of colon cancer. $^{14-18}$

Fasting serum amidated gastrin levels have been shown to be elevated in patients with colorectal cancer compared with controls and to decrease after apparently curative resection of the tumour, suggesting that the elevated serum gastrin seen in these patients may be due, at least in part, to secretion of gastrin by the tumour. This was mainly accounted for by a subgroup of patients who had significantly elevated levels. ${ }^{19-24}$ Kameyama and colleagues ${ }^{25}$ found higher serum gastrin levels in patients with colorectal cancer liver metastases. However, none of these studies controlled for the presence of gastric colonisation with Helicobacter pylori, a common infection resulting in chronic gastritis and significantly increased fasting and meal stimulated gastrin levels that decrease after eradication of the organism. It is likely that the subgroups with significantly elevated serum gastrin levels had $H$ pylori infection. Thorburn and colleagues ${ }^{26}$ found that serum gastrin levels above the normal range $(>90 \mathrm{pg} / \mathrm{ml})$ were associated with a 3.9fold increased risk of colorectal cancer. Other studies however have found no association between colorectal neoplasia and hypergastrinaemia. ${ }^{27-33}$

Penman and colleagues ${ }^{34}$ found that when confounding factors which increase serum gastrin levels $\left(\mathrm{H}_{2}\right.$ antagonists, proton pump inhibitors, hypercalcaemia, renal impairment, pernicious anaemia, and $H$ pylori infection) are

Abbreviations used in this paper: ELISA, enzyme linked immunosorbent assay.

Correspondence to:

s.b.kelly@ncl.ac.uk 
Table 1 Patient demographics in the cancer, polyp, and control groups

\begin{tabular}{|c|c|c|c|c|c|c|}
\hline & \multicolumn{2}{|c|}{ Cancers $(n=57)$} & \multicolumn{2}{|c|}{ Polyps $(n=29)$} & \multicolumn{2}{|c|}{ Controls $(n=53)$} \\
\hline & $H P+v e$ & $H P-v e$ & $H P+v e$ & $H P-v e$ & $H P+v e$ & $H P-v e$ \\
\hline Number & 34 & 23 & 18 & 11 & 29 & 24 \\
\hline $\operatorname{Sex}(M: F)$ & $22: 12$ & $10: 13$ & $11: 7$ & $8: 3$ & $8: 21$ & $13: 11$ \\
\hline Mean age (y) & 69 & 70 & 66 & 63 & 55 & 56 \\
\hline (range) & $42-84$ & $48-82$ & $42-86$ & $46-75$ & $27-79$ & $35-76$ \\
\hline \multicolumn{7}{|l|}{ Location } \\
\hline Caecum & 4 & 4 & 2 & & & \\
\hline Ascending colon & 2 & 2 & 2 & & & \\
\hline Hepatic flexure & & 1 & & & & \\
\hline Transverse colon & 5 & & & & & \\
\hline Splenic flexure & & & 1 & 1 & & \\
\hline Descending colon & & & 4 & & & \\
\hline Sigmoid colon & 8 & 7 & 7 & 8 & & \\
\hline Rectosigmoid & & 2 & 1 & & & \\
\hline Rectum & 15 & 9 & 5 & 4 & & \\
\hline \multicolumn{7}{|l|}{ Dukes' stage } \\
\hline A & 2 & 5 & & & & \\
\hline B & 14 & 9 & & & & \\
\hline $\mathrm{C}$ & 16 & 11 & & & & \\
\hline Inoperable & 2 & & & & & \\
\hline \multicolumn{7}{|l|}{ Type of polyp } \\
\hline Tubulovillous adenoma & & & 13 & 11 & & \\
\hline Tubular adenoma & & & 9 & 2 & & \\
\hline \multicolumn{7}{|l|}{ Degree of dysplasia } \\
\hline Mild & & & 10 & & & \\
\hline Moderate & & & 10 & 12 & & \\
\hline Severe & & & 2 & 1 & & \\
\hline \multicolumn{7}{|l|}{ Diagnosis in controls } \\
\hline Normal & & & & & 23 & 20 \\
\hline Diverticular disease & & & & & 6 & 4 \\
\hline
\end{tabular}

controlled for, plasma gastrin levels are not increased in patients with colorectal cancer and do not decrease after curative resection. $H$ pylori significantly increases fasting and meal stimulated gastrin levels that decrease after eradication of the organism. Previously noted decreases in gastrin levels in patients after tumour resection may be attributable to loss of $H$ pylori infection in some patients as a result of administration of perioperative antibiotics. However, Penman and colleagues ${ }^{34}$ only measured levels of fully processed amidated gastrin in the serum of patients with colorectal carcinoma.

Dickinson $^{35}$ suggested that the conflicting results observed in human studies can be explained by differences in the types of gastrin being detected. The fully processed form of gastrin (amidated gastrin 17) is the form detected by most commercial assays and is the type of gastrin which has been most studied in the past. However, unprocessed forms of gastrin (progastrin and glycine extended gastrin) also cause cell proliferation. The aim of this study was to determine whether fasting serum levels of progastrin, amidated gastrin, or glycine extended gastrin are elevated in patients with colorectal cancer or colorectal polyps compared with control subjects.

\section{Patients and methods}

PATIENTS

We studied 57 patients with newly diagnosed, histologically proved, sporadic colorectal cancers, 29 patients with colorectal polyps, and 53 controls. Patients undergoing colonoscopy for bowel symptoms and who were found to have normal mucosa or diverticular disease were used as controls. Patients with incomplete colonoscopy, inadequate bowel preparation, metaplastic polyps, or inflammatory bowel dis- ease were excluded. Patients and controls with any of the following conditions were excluded from the study, as these conditions are known to raise plasma gastrin levels: peptic ulcer disease, previous gastric surgery including gastrectomy, vagotomy, pyloroplasty or gastrojejunostomy, small bowel resection, pernicious anaemia, treatment with acid suppressing drugs $\left(\mathrm{H}_{2}\right.$ antagonists or proton pump inhibitors), renal failure, hypercalcaemia, recent antibiotic therapy (within one week), patients requiring emergency surgery, or patients with intestinal obstruction. In addition, patients with familial adenomatous polyposis or malignancy at another site were excluded. Informed consent was obtained from all patients and controls and the study was approved by the Newcastle and North Tyneside ethics committee. All blood samples from patients and controls were collected from North Tyneside General Hospital.

BLOOD SAMPLE COLLECTION

Blood samples (10 $\mathrm{ml}$ of venous blood) were drawn after an overnight fast from patients with colorectal cancer on the morning of surgery. Fasting blood samples were obtained from 29 patients with colorectal polyps and 53 controls following colonoscopy. Blood samples were collected into lithium-heparin tubes and centrifuged at $3000 \mathrm{rpm}$ for 10 minutes at $4^{\circ} \mathrm{C}$ and the separated plasma was stored at $-20^{\circ} \mathrm{C}$ until assayed.

DETERMINATION OF H PYLORI STATUS

The presence or absence of $H$ pylori infection was determined by an enzyme linked immunosorbent assay (ELISA). This assay detects serum antibodies (IgG) to $H$ pylori in plasma.

\section{GASTRIN ANALYSIS}

Progastrin derived peptides in human plasma were estimated by radioimmunoassay using three different antibodies, as previously described. ${ }^{36}$ In all assays, standard curves were prepared with the appropriate volume of plasma stripped of gastrin. Intact progastrin was assayed using antibody L289, which reacts with $\mathrm{C}$ terminal fragments of progastrin longer than six residues. $\mathrm{C}$ terminal glycine extended gastrins were detected with monoclonal antibody 109-21 (a gift from Dr JH Walsh, UCLA). COOH terminal amidated gastrins were assayed with antibody L2.

The "limit of detection"- that is, the sensitivity of the assay-was $4 \mathrm{pmol} / 1$ for antibody L2 which detects amidated gastrin. The sensitivity of the 109-21 assay for glycine extended gastrin was $20 \mathrm{pmol} / \mathrm{l}$ and the sensitivity of the L289 assay was $15 \mathrm{pmol} / \mathrm{l}$.

STATISTICAL ANALYSIS

Statistical analysis was by the Kruskal-Wallis test and Spearman's rank correlation coefficient.

\section{Results}

PATIENT DEMOGRAPHICS

Patient demographics are listed in table 1. In the $H$ pylori positive group with carcinoma, the 


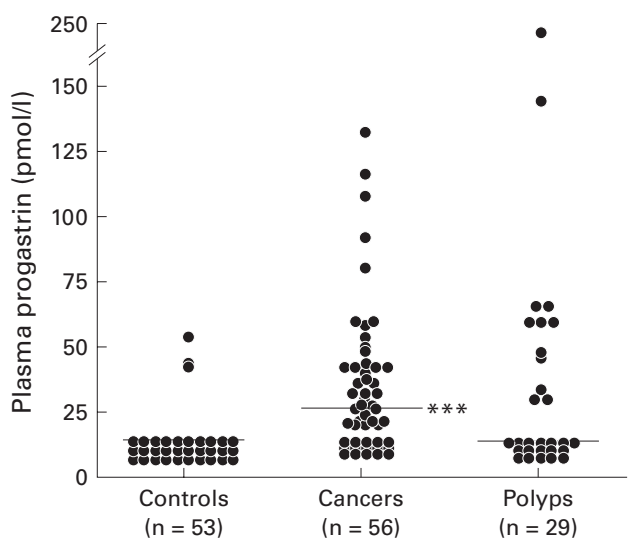

Figure 1 Plasma progastrin levels in control, cancer, and polyp groups. Median values are shown ( ${ }^{\star *} p=0.0001$, cancers $v$ controls and polyps).

Table 2 Amidated gastrin levels in control, cancer, and polyp groups

\begin{tabular}{llll}
\hline & $\begin{array}{l}\text { Amidated gastrin } \\
(\text { pmol/l) }\end{array}$ & $\begin{array}{l}\text { Percentage of group } \\
\leqslant 4 \text { pmolll }\end{array}$ & Number \\
\hline Control & $10(<4-780)$ & 15.1 & 53 \\
Cancer & $13(<4-520)$ & 17.5 & 57 \\
Polyp & $24(<4-1600)$ & 10.3 & 29 \\
\hline *Values are median (range). Differences in median levels of
\end{tabular}
amidated gastrin between groups was not significant.

Dukes' classification was not available in two patients as they were inoperable but preoperative biopsies were positive for carcinoma in both patients. In one patient, the carcinoma was found to be arising in a polyp. All patients had one carcinoma and four patients also had a polyp present. This was a tubulovillous adenoma in three patients and a tubular adenoma in one patient. In the $H$ pylori negative group with carcinoma, two patients had two rectal cancers, both of which were Dukes' stage B. One patient had one cancer in the ascending colon and one at the hepatic flexure, both of which were Dukes' stage B. In three patients, the carcinoma was found to be arising in a polyp. Two more patients had one polyp each, both of which were tubulovillous adenomas.

In the $H$ pylori positive group with polyps, 14 patients had one polyp and four patients had two polyps. Three of the patients with two polyps had two tubulovillous adenomas and one had two tubular adenomas. In the $H$ pylori negative group with polyps, 10 patients had one polyp and one patient had three polyps.

PLASMA GASTRIN LEVELS

Median progastrin levels in the cancer group (27.5 pmol/1 (range <15-132)) were significantly higher than in either the control group $(\leqslant 15 \mathrm{pmol} / 1 \quad(<15-54)) \quad(\mathrm{p}=0.0001)$ or the polyp group $(\leqslant 15 \mathrm{pmol} / 1 \quad(<15-240))$ ( $\mathrm{p}=0.0001$, Kruskal-Wallis test) (fig 1). In the control group, 49 of $53(92.5 \%)$ patients had progastrin levels $<15 \mathrm{pmol} / \mathrm{l}$ compared with 17 of $29(58.6 \%)$ in the polyp group and 15 of 56 $(26.8 \%)$ in the cancer group. Progastrin levels were not measured in one patient with cancer due to an insufficient sample. Median amidated gastrin levels did not differ significantly between groups (table 2). The cancer group were significantly older than the control and
Table 3 Relationship of progastrin levels to age in control, cancer and polyp groups

\begin{tabular}{llllll}
\hline & \multicolumn{2}{l}{ Age $\leqslant 69$ years } & & \multicolumn{2}{l}{ Age $\geqslant 70$ years } \\
\cline { 2 - 3 } \cline { 5 - 6 } $\begin{array}{lllll}\text { Progastrin } \\
\text { (pmoll) }\end{array}$ & Number & & $\begin{array}{l}\text { Progastrin } \\
\text { (pmolll) }\end{array}$ & Number \\
\hline Control & $\leqslant 15$ & 48 & $\leqslant 15$ & 5 \\
Cancer $^{\star}$ & 27 & 25 & & 28 & 31 \\
Polyp & $\leqslant 15$ & 18 & & 15 & 11 \\
\hline
\end{tabular}

* Progastrin levels are median values and are higher in cancer patients than controls or in patients with polyps, irrespective of age.

Table 4 Effect of $H$ pylori status on progastrin levels

\begin{tabular}{|c|c|c|c|c|}
\hline \multirow[b]{2}{*}{ Group } & \multicolumn{2}{|c|}{ H pylori -ve } & \multicolumn{2}{|c|}{ H pylori $+v e$} \\
\hline & $\begin{array}{l}\text { Progastrin } \\
\text { (pmol/l) }\end{array}$ & Number & $\begin{array}{l}\text { Progastrin } \\
\text { (pmol/l) }\end{array}$ & Number \\
\hline Control & $\leqslant 15$ & 24 & $\leqslant 15$ & 29 \\
\hline Cancer & 21 & 23 & 32 & 33 \\
\hline Polyp & 48 & 11 & $\leqslant 15$ & 18 \\
\hline Overall & $\leqslant 15^{\star}$ & 58 & $\leqslant 15^{\star}$ & 80 \\
\hline $\begin{array}{l}\text { Overall \% } \\
\quad(\leqslant 15)\end{array}$ & 55 & & 61 & \\
\hline
\end{tabular}

^The effect of $H$ pylori on progastrin levels was not significant.

polyp groups and a preliminary analysis showed progastrin to be significantly related to age. However, as table 3 demonstrates, comparing levels of progastrin within age groups shows that progastrin levels were higher in cancer patients, irrespective of age. Thus the apparent association between age and progastrin is likely to be due to the age imbalance of the groups and therefore spurious. There was no apparent relationship between age and amidated gastrin (Spearman rank correlation coefficient $0.05 ; p=0.5)$. There was no significant difference in progastrin levels between the sexes (Kruskal-Wallis test, $\mathrm{p}=0.3$ ). There was borderline significance in median amidated gastrin levels between the sexes (males 9.5 $\mathrm{pmol} / \mathrm{l}$, females $16 \mathrm{pmol} / \mathrm{l})(\mathrm{p}=0.08)$.

The groups were fairly well matched in terms of proportion of $H$ pylori positive patients; $55 \%$ of the control group, $60 \%$ of the cancer group, and $62 \%$ of the polyp group. There was no statistically significant effect of $H$ pylori status on progastrin levels (table 4). Amidated gastrin levels were significantly higher in $H$ pylori positive patients $(19 \mathrm{pmol} / \mathrm{l})$ than in $H$ pylori negative patients ( $8 \mathrm{pmol} / \mathrm{l})$ (Kruskal-Wallis test, $\mathrm{p}=0.0022$ ) (table 5). There was no significant difference in plasma levels of progastrin or amidated gastrin depending on the site (Kruskal Wallis, $\mathrm{p}=0.9$ and $\mathrm{p}=0.4$, respectively), Dukes' stage (Kruskal Wallis, $p=0.2$ and $\mathrm{p}=1$ ) (table 6$)$ or grade (Kruskal Wallis, $\mathrm{p}=0.4$ and $\mathrm{p}=0.2$ ) (table 7 ) of the cancer. There was no significant difference in plasma levels of progastrin or amidated gastrin between tubulovillous adenomas and tubular adenomas. Median plasma progastrin levels were significantly higher for moderately dysplastic polyps (38 pmol/l) $(\mathrm{n}=18)$ compared with mildly dysplastic polyps $(15 \mathrm{pmol} / \mathrm{l})(\mathrm{n}=8)$ and severely dysplastic polyps (15 pmol/l) $(\mathrm{n}=3)$ (Kruskal-Wallis test, $\mathrm{p}=0.05)$. There was no significant difference in amidated gastrin levels between groups $(\mathrm{p}=0.1)$. 
Table 5 Effect of $H$ pylori status on amidated gastrin levels

\begin{tabular}{|c|c|c|c|c|}
\hline \multirow[b]{2}{*}{ Group } & \multicolumn{2}{|l|}{ H pylori -ve } & \multicolumn{2}{|l|}{ H pylori $+v e$} \\
\hline & $\begin{array}{l}\text { Amidated gastrin } \\
(\text { pmolll) }\end{array}$ & Number & $\begin{array}{l}\text { Amidated gastrin } \\
(\text { pmolll) }\end{array}$ & Number \\
\hline Control & 6.5 & 24 & 16 & 29 \\
\hline Cancer & 8 & 23 & 15 & 33 \\
\hline Polyp & 9 & 11 & 27 & 18 \\
\hline Overall & $8^{\star}$ & 58 & $19^{\star}$ & 80 \\
\hline Overall $\%(\leqslant 4)$ & 17 & & 14 & \\
\hline
\end{tabular}

${ }^{\star}$ Median amidated gastrin levels were significantly higher in $H$ pylori positive than in $H$ pylori negative patients, $\mathrm{p}=0.0022$ (Kruskal-Wallis test)

Table 6 Effect of Dukes'stage on progastrin and amidated gastrin levels

\begin{tabular}{lcllll}
\hline $\begin{array}{l}\text { Dukes, } \\
\text { stage }\end{array}$ & Number & $\begin{array}{l}\text { Median } \\
\text { progastrin } \\
\text { (pmolll) }\end{array}$ & $\begin{array}{l}\text { Number }(\%) \\
\text { progastrin } \\
\leqslant 15 \text { pmol/l }\end{array}$ & $\begin{array}{l}\text { Median amidated } \\
\text { gastrint (pmoll) }\end{array}$ & $\begin{array}{l}\text { Number (\%) } \\
\text { amidated gastrin } \\
\leqslant 4 \text { pmol/l }\end{array}$ \\
\hline $\mathrm{A}$ & 7 & 22 & $3(42.9)$ & 20 & $3(42.9)$ \\
$\mathrm{B}$ & 21 & $24(\mathrm{n}=20)$ & $5(23.8)$ & 11 & $4(19.1)$ \\
$\mathrm{C}$ & 27 & 42 & $6(22.2)$ & 12 & $3(11.1)$ \\
\hline
\end{tabular}

ॠThere was no significant effect of Dukes' stage on progastrin levels (Kruskal-Wallis, $p=0.2$ ).

†There was no significant effect of Dukes' stage on amidated gastrin levels (Kruskal-Wallis, $p=1$ ).

Table 7 Effect of grade of carcinoma on progastrin and amidated gastrin levels

\begin{tabular}{lcll}
\hline Grade & Number & $\begin{array}{l}\text { Median progastrin } \\
(\text { pmolll) }\end{array}$ & $\begin{array}{l}\text { Median amidated } \\
\text { gastrint (pmol/l) }\end{array}$ \\
\hline Well differentiated & 6 & 33 & 49.5 \\
Moderately differentiated & 42 & $30(\mathrm{n}=41)$ & 11 \\
Poorly differentiated & 6 & 17.5 & 18.5
\end{tabular}

*There was no significant effect of grade of the carcinoma on progastrin levels (Kruskal-Wallis, $\mathrm{p}=0.4)$.

†There was no significant effect of grade of the carcinoma on amidated gastrin levels (Kruskal-Wallis, $\mathrm{p}=0.2$ ). mature forms of gastrin) were significantly higher in both $H$ pylori positive and $H$ pylori negative groups with colorectal cancer compared with the respective $H$ pylori positive and negative control groups. Their results show that there is preferential secretion of nonamidated gastrin forms other than glycine extended gastrin in patients with colorectal carcinoma. In our study, we found that the median progastrin level in the cancer group (27.5 pmol/l) was significantly higher than in either the polyp group $(\leqslant 15 \mathrm{pmol} / \mathrm{l})$ or the control group $(\leqslant 15 \mathrm{pmol} / \mathrm{l})(\mathrm{p}=0.0001)$. Our results therefore support this hypothesis. We have demonstrated that progastrin is likely to be one of the forms of non-amidated gastrin suggested by Ciccotosto and colleagues. ${ }^{37}$

Ciccotosto and colleagues ${ }^{37}$ also reported that $H$ pylori positive patients with colorectal cancer had significantly higher levels of circulating non-amidated gastrin than $H$ pylori negative patients (5.2-fold and 2.3-fold, respectively). In contrast, we were unable to find any significant effect of $H$ pylori on progastrin levels. Smith and colleagues ${ }^{38}$ found that plasma levels of progastrin, amidated gastrin, and glycine extended gastrin were normal in patients with colorectal polyps. This is in agreement with our findings. They concluded that despite the autocrine production of gastrin by polyps, this is not reflected by elevated circulating gastrin levels. It is likely that the amount of gastrin produced by a small polyp is too small to contribute significantly to circulating plasma gastrin. We excluded patients with hyperplastic polyps from our study. Smith and colleagues $^{22}$ and Seitz and colleagues ${ }^{24}$ also excluded such patients. By contrast, Kikendall and colleagues ${ }^{29}$ included patients with hyperplastic polyps in the control group.

According to the second mechanism, hypergastrinaemia is the primary event which leads to induction and promotion of tumour growth. ${ }^{31}$ Talley and colleagues ${ }^{39}$ demonstrated an increased risk of colorectal cancer in the first five years after diagnosis of pernicious anaemia but the overall risk did not reach statistical significance. Brinton and colleagues ${ }^{40}$ showed no evidence of an increased long term risk of colorectal cancer in patients with pernicious anaemia. Smith and colleagues ${ }^{41}$ have shown that pernicious anaemia patients have elevated total gastrin levels and that this is mainly due to increased levels of progastrin and glycine extended gastrin. Patients with hypergastrinaemia caused by Zollinger-Ellison syndrome have an increased rate of colonic mucosal cell proliferation but do not have an increased risk of colonic adenomas ${ }^{1}$ or colorectal cancer. ${ }^{42}$ Graffner and colleagues ${ }^{43}$ showed no trophic effects of endogenous hypergastrinaemia induced by omeprazole on the murine MC-26 colon cancer cell line.

Older patients might be expected to have a higher frequency of severe atrophic gastritis which is associated with high plasma amidated gastrin levels. ${ }^{44}$ However, in our study we found no relationship between age and amidated gastrin levels. In this study, we did not try to exclude patients with atrophic gastritis as this 
would have required upper gastrointestinal endoscopy with biopsies. The cancer group (mean age 70 years) was older than the polyp group (mean age 65 years) or the control group (mean age 56 years). There were more men in the cancer group ( 32 men and 25 women) and polyp group ( 20 men and 10 women) and more women in the control group (26 men and 40 women). In this study, we found no association between age or sex and progastrin levels.

A number of previous studies have shown elevated levels of amidated gastrin in patients with colorectal neoplasia but none of these studies controlled for the presence of $H$ pylori. ${ }^{19-24}$ In addition, these studies only measured levels of circulating amidated gastrin and not progastrin or glycine extended gastrin. Apart from this study, there has only been one other study which controlled for the presence of $H$ pylori and which measured unprocessed and partially processed gastrins in patients with colorectal cancer. ${ }^{37}$ We found that amidated gastrin levels were significantly higher in $H$ pylori positive patients compared with $H$ pylori negative patients. These findings are similar to Penman and colleagues ${ }^{34}$ but at odds with Ciccotosto and colleagues. ${ }^{37}$ Ciccotosto and colleagues ${ }^{37}$ have also shown that fasting amidated gastrin levels for the $H$ pylori positive group with colorectal cancer were significantly higher than those for the $H$ pylori positive control group. By contrast, we found no significant difference between these two groups (table 5). Smith and colleagues ${ }^{22}$ and Seitz and colleagues $^{24}$ found significantly elevated gastrin levels in patients with colorectal polyps and colorectal cancer compared with controls. Gastrin levels were modestly elevated in patients with polyps but patients with colorectal cancer had markedly elevated gastrin levels.

All but two controls in our study had levels of glycine extended gastrin which were below $20 \mathrm{pmol} / \mathrm{l}$. This was the "limit of detection" of our assay which was higher than for the other forms of gastrin and higher than the assay used by Ciccotosto and colleagues. ${ }^{37}$ Ciccotosto and colleagues $^{37}$ found that glycine extended gastrin was detected in $44 \%$ of tumours. They found that fasting levels of glycine extended gastrin in $H$ pylori positive $(16 \pm 4 \mathrm{pmol} / \mathrm{l})$ and $H$ pylori negative $(12 \pm 2 \mathrm{pmol} / \mathrm{l})$ patients with colorectal cancer were significantly lower than in $H$ pylori positive $(22 \pm 6 \mathrm{pmol} / \mathrm{l})$ and $H$ pylori negative $(21 \pm 1 \mathrm{pmol} / \mathrm{l})$ controls, respectively.

There were a large number of patients with advanced carcinomas in our series. Our study contained seven Dukes' A patients (12.7\%), 21 Dukes' B patients (38.2\%), and 27 Dukes' C patients $(49.1 \%)$. This compares with $31 \%$ with advanced disease (Dukes' B, C, or D) reported by Kikendall and colleagues, ${ }^{29} 55 \%$ (Dukes' B or C) reported by Smith and colleagues, ${ }^{22}$ and $61 \%$ (Dukes' $\mathrm{B}, \mathrm{C}$, or D) reported by Seitz and colleagues. ${ }^{24}$ We found no relationship between progastrin levels and the malignant potential of cancers, as measured by the Dukes' stage or grade of the tumour (tables 6, 7). However, in the analysis of tumour grade (table 7) the numbers are skewed between the groups such that the results are not likely to be meaningful (that is, 42 moderately differentiated carcinomas compared with six in each of the well and poorly differentiated groups). When analysing the degree of dysplasia of the polyps, median progastrin level was significantly higher for moderately dysplastic polyps $(p=0.05)$. However, the numbers are again skewed between the groups such that the results are not likely to be meaningful (that is, 18 moderately dysplastic polyps, eight mildly dysplastic polyps, and three severely dysplastic polyps).

Differences in results between studies may reflect different statistical analyses of samples lacking a normal distribution and containing outliers. Recognition of these outliers is crucial to interpretation of the results. Several studies contained outliers which occurred mainly in the cancer group and which were significantly higher than controls. ${ }^{20} 22$ In our study, there were 10 outliers in the amidated gastrin group (controls, polyps, and cancers) and only five outliers in the progastrin group (controls, polyps, and cancers). The mean level of amidated gastrin in the outliers was $437 \mathrm{pmol} / 1$ and the mean level of progastrin was $148 \mathrm{pmol} / \mathrm{l}$. These outliers could not therefore have accounted for the observed differences in progastrin levels in our study.

Progastrin, the primary translation product of gastrin, requires extensive post-translational processing to amidated gastrin for full biological activity. This occurs through the so called "regulated route". Ciccotosto and colleagues ${ }^{37}$ found that progastrin, amidated gastrin, total gastrin, and glycine extended gastrin were present in $100 \%, 69 \%, 56 \%$, and $44 \%$ of colorectal cancers, respectively. They suggested that progastrins may not be stored in tumours but rather secreted from tumour cells into the extracellular milieu by an alternative secretory pathway, the so called "constitutive route". This route takes material direct from the Golgi to the cell surface. They found that plasma levels of total but not processed gastrins were increased in patients with colorectal carcinoma. Nemeth and colleagues ${ }^{9}$ found that most colorectal cancers contain peptides derived from the gastrin precursor, progastrin, but these tumours do not usually convert progastrin to amidated gastrin. Kochman and colleagues ${ }^{45}$ have shown that progastrin is 700fold more abundant in colorectal cancer than the adjacent normal mucosa and that the ratio of gastrin precursors to gastrin is significantly increased in neoplastic colonic mucosa compared with normal colonic tissue. Progastrin or progastrin derived peptides have been detected in $80-100 \%$ of colorectal carcinomas. ${ }^{46}$ Van Solinge and colleagues ${ }^{47}$ found that human colon carcinomas and normal colonic tissues express the gastrin gene at both mRNA and peptide levels but post-translational maturation is incomplete. Progastrins were detected in all tumours, cell lines, and normal colonic tissue but amidated gastrins occurred rarely. They found that the concentration of progastrin was 10-fold higher in colon carcinomas than in normal colonic tissue. 
The results of this study are clearly important and need to be investigated further. We are currently measuring plasma progastrin levels in patients before and after resection of colorectal cancer to see if progastrin levels fall following curative resection of the tumour. We are also measuring progastrin levels in patients with recurrent disease to determine whether plasma progastrin levels may act as a marker for tumour recurrence. This may have important implications for screening strategies for colorectal cancer. If circulating progastrin is an important growth factor for colorectal cancer, then substances which decrease the levels of circulating progastrin or block its effect, for example, gastrin receptor antagonists and antigastrin antibodies, may be effective in regulating tumour growth and may have important implications for therapy.

We are grateful for the financial support received from Northumbria Health Care NHS Trust and the Astra Foundation. We would also like to acknowledge the help of Andrea Varro, Department of Physiology, University of Liverpool, Englarro, Department of Physiology, Univers
land for perming the gastrin assays.

1 Sobhani I, Lehy $\mathrm{T}$, Laurent-Puig $\mathrm{P}$, et al. Chronic endogenous hypergastrinaemia in humans: evidence for a mitogenic effect on the colonic mucosa. Gastroenterology mitogenic effect

2 Renga M, Brandi G, Paganelli GM, et al. Rectal cell proliferation and colon cancer risk in patients with hypergastrinaemia. Gut 1997;41:330-2.

3 Kusyk CJ, McNiel NO, Johnson LR. Stimulation of growth of a colon cancer cell line by gastrin. Am $\mathcal{f}$ Physio 1986;251:G597-601

4 Watson SA, Durrant LG, Crosbie JD, et al. The in vitro growth response of primary human colorectal and gastric cancer cells to gastrin. Int f Cancer 1989;43:692-6.

5 Winsett OE, Townsend CM Jr, Glass EJ, et al. Gastrin stimulates growth of colon cancer. Surgery 1986;99:302-7.

6 Karlin DA, McBath M, Jones RD, et al. Hypergastrinaemia and colorectal carcinogenesis in the rat. Cancer Lett 1985;29:73-8.

7 Luttichau HR, Van Solinge WW, Nielsen FC, et al. Developmental expression of the gastrin and cholecystokinin genes in rat colon. Gastroenterology 1993;104:1092-8.

8 Hollande F, Imdahl A, Mantamadiotis T, et al. Glycineextended gastrin acts as an autocrine growth factor in a nontransformed colon cell line. Gastroenterology 1997;113: nontransforn

9 Nemeth J, Taylor B, Pauwels S, et al. Identification of progastrin derived peptides in colorectal carcinoma extracts. Gut 1993;34:90-5.

10 Seva C, Dickinson CJ, Yamada T. Growth-promoting effects of glycine-extended progastrin. Science 1994;265:410-12.

11 Wang TC, Koh TJ, Varro A, et al. Processing and proliferative effects of human progastrin in transgenic mice. $\mathcal{F}$ Clin Invest 1996;98:1918-29.

12 Koh TJ, Goldenring JR, Ito S, et al. Gastrin deficiency results in altered gastric differentiation and decreased colonic proliferation in mice. Gastroenterology 1997;113. colonic pro

13 Upp JR Jr, Singh P, Townsend CM Jr, et al. Clinical significance of gastrin receptors in human colon cancers. Cancer Res 1989;49:488-92.

14 Beauchamp RD, Townsend CM Jr, Sing $\mathrm{P}$, et al. Proglumide, a gastrin receptor antagonist, inhibits growth Proglumide, a gastrin receptor antagonist, inhibits growth of colon cancer

15 Hoosein NM, Kiener PA, Curry RC, et al. Antiproliferative effects of gastrin receptor antagonists and antibodies to gastrin on human colon carcinoma cell lines. Cancer Res 1988;48:7179-83.

16 Romani R, Howes LG, Morris DL. Gastrin receptor antagonist Cl-988 inhibits growth of human colon cancer in vivo and in vitro. Aust N Z F Surg 1996;66:235-7.

17 Watson SA, Clifford T, Sykes RE, et al. Gastrin sensitivity of primary human colorectal cancer: the effect of gastrin receptor antagonism. Eur f Cancer 1995;31A:2086-95.

18 Watson SA, Michaeli D, Grimes S, et al. Gastrimmune raises antibodies that neutralize amidated and glycine-extended gastrin-17 and inhibit the growth of colon cancer. Cancer Res 1996:56:880-5.

19 Charnley RM, Thomas WM, Stanley J, et al. Serum gastrin concentrations in colorectal cancer patients. Ann R Coll Surg Engl 1992;74:138-41.

20 Wong K, Beardshall K, Waters CM, et al. Postprandial hypergastrinaemia in patients with colorectal cancer. Gut 1991;32:1352-4.

21 Lambert JR, Eaves ER, Soveny C, et al. Serum gastrin in colonic polyps. Gastroenterology 1988;94:A248.

22 Smith JP, Wood JG, Solomon TE. Elevated gastrin levels in patients with colon cancer or adenomatous polyps. Dig Dis Sci 1989;34:171-4.

23 Mihas AA, Maliakkal RJ, Sheuke M, et al. Serum gastrin levels in patients with colorectal cancer and adenomatous polyps: a prospective study. Res Comm Mol Pathol Pharmacol 1995;90:301-4

24 Seitz JF, Giovannini M, Gouvernet J, et al. Elevated serum gastrin levels in patients with colorectal neoplasia. F Clin Gastroenterol 1991;13:541-5.

25 Kameyama M, Fukuda I, Imaoka S, et al. Level of serum gastrin as a predictor of liver metastasis from colorectal gastrin as a predictor of liver metastasis fron

26 Thorburn CM, Friedman GD, Dickinson CJ, et al. Gastrin and colorectal cancer: A prospective study. Gastroenterology 1998;115:275-80

27 Suzuki H, Matsumoto K, Terashima H. Serum levels of gasrin in patients with colorectal neoplasia. Dis Colon Rectum 1988;31:716-17.

28 Yapp R, Modlin IM, Kumar RR, et al. Gastrin and colorectal cancer. Evidence against an association. Dig Dis Sci 1992;37:481-4.

29 Kikendall JW, Glass AR, Sobin LH, et al. Serum gastrin is not higher in subjects with colonic neoplasia. Am $\mathcal{f}$ Gastroenterol 1992;87:1394-7.

30 Niv Y, Heizelracht N, Lamprecht SA, et al. Gastrin levels in colorectal cancer. Isr f Med Sci 1997;33:186-9.

31 Vanderstraeten EF, De Vos MM, Versieck JM, et al. Serum gastrin levels and colorectal neoplasia. Dis Colon Rectum 1995;38:172-6.

32 Lamberts R, Wartenberg T, Creutzfeldt W. Role of circulating gastrin in colorectal adenomas and carcinomas. Digestion 1999;60:101-9.

33 Fontanesi BV, Boris B, Delcio M, et al. Gastrin levels in patients with colorectal cancer. Hepatogastroenterology 1997;44:1082-4.

34 Penman ID, El-Omar E, Ardill JES, et al. Plasma gastrin concentrations are normal in patients with colorectal neoplasia and unaltered following tumour resection. Gastroenterology 1994;106:1263-70.

35 Dickinson CJ. Relationship of gastrin processing to colon cancer. Gastroenterology 1995;109:1384-8.

36 Varro A, Dockray GJ, Bate GW, et al. Gastrin biosynthesis in the antrum of patients with pernicious anemia. Gastroenterology 1997;112:733-41.

37 Ciccotosto GD, McLeish A, Hardy KJ, et al. Expression, processing and secretion of gastrin in patients with colorectal carcinoma. Gastroenterology 1995;109:1142-53.

38 Smith AM, Varro A, Watson SA. Serum gastrin levels are normal in patients with colorectal polyps. Gastroenterology 1998;114:A1182, G4833.

39 Talley NJ, Chute CG, Larson DE, et al. Risk for colorectal denocarcinoma in pernicious anaemia. Ann Intern Med 1989;111:738-42.

40 Brinton LA, Gridley G, Hrubec Z, et al. Cancer risk following pernicious anaemia. Br f Cancer 1989;59:810-13.

41 Smith AM, Varro A, Watson SA, et al. Progastrin and glycine extended gastrin-17 are overexpressed in pernicious anaemia patients. Gastroenterology 1998;114:A1181, G4831.

42 Orbuch M, Venzon DJ, Lubensky IA, et al. Prolonged hypergastrinaemia does not increase the frequency of colonic neoplasia in patients with Zollinger-Ellison syndrome. Dig Dis Sci 1996;41:604-13.

43 Graffner H, Singh G, Chaudry I, et al. Omeprazole-induced hypergastrinemia does not influence growth of colon carcinoma. Dig Dis Sci 1992;4:485-9.

44 Varis K, Ihamaki T, Harkonen M, et al. Gastric morphology, function, and immunology in first-degree relatives of probands with pernicious anemia and controls. Scand $\mathcal{F}$ Gastroenterol 1979;14:129-39.

45 Kochman ML, DelValle J, Dickinson CJ, et al. Posttranslational processing of gastrin in neoplastic human colonic tissues. Biochem Biophys Res Comm 1992;189:1165-

46 Baldwin GS, Shulkes A. Gastrin, gastrin receptors and colorectal carcinoma. Gut 1998;42:581-4

47 Van Solinge WW, Nielsen FC, Friis-Hansen L, et al. Expression but incomplete maturation of progastrin in colorectal carcinomas. Gastroenterology 1993;104:1099-107. 